\title{
Repeated erosion of cohesive sediments with biofilms
}

\author{
K. Valentine ${ }^{1, *}$, G. Mariotti ${ }^{1, * *}$, and S. Fagherazzi ${ }^{1}$ \\ ${ }^{1}$ Department of Earth and Environment, Boston University, 22015 Boston, USA \\ *now at: Boston College, 02467 Chestnut Hill, USA \\ ** now at: Massachusetts Institute of Technology, 02139 Cambridge, USA \\ Correspondence to: K. Valentine (kendallv@bu.edu)
}

Received: 15 October 2013 - Revised: 24 December 2013 - Accepted: 7 January 2014 - Published: 1 April 2014

\begin{abstract}
This study aims to explore the interplay between biofilms and erodability of cohesive sediments. Erosion experiments were run in four laboratory annular flumes with natural sediments. After each erosion the sediment was allowed to settle, mimicking intermittent physical processes like tidal currents and waves. The time between consecutive erosion events ranged from 1 to 12 days. Turbidity of the water column caused by sediment resuspension was used to determine the erodability of the sediments with respect to small and moderate shear stresses. Erodability was also compared on the basis of the presence of benthic biofilms, which were quantified using a Pulse-Amplitude Modulation (PAM) Underwater Fluorometer. We found that frequent erosion lead to the establishment of a weak biofilm, which reduced sediment erosion at small shear stresses (around 0.1 Pa). If prolonged periods without erosion were present, the biofilm fully established, resulting in lower erosion at moderate shear stresses (around $0.4 \mathrm{~Pa}$ ). We conclude that an unstructured extracellular polymeric substances (EPS) matrix always affect sediment erodability at low shear stresses, while only a fully developed biofilm mat can reduce sediment erodability at moderate shear stresses.
\end{abstract}

\section{Introduction}

Muddy coastlines are common in macrotidal environments and near large rivers and deltas, hosting highly productive ecosystems (Woodroffe, 2002). The cohesive sediments forming mudflats are constantly reworked by waves and currents giving rise to an ever-changing landscape (deJonge and van Beusekom, 1995; Mariotti and Fagherazzi, 2013; Fagherazzi and Mariotti, 2012). A full understanding of the mechanisms responsible for the erosion of cohesive sedi- ments in mudflats is therefore important for the preservation of these delicate environments.

The purpose of this study is to examine the effects of repeated erosion events on the same cohesive sediment surface under similar conditions, elucidating how biotic and abiotic time-dependent processes affect erodability on a time scale on the order of weeks.

Historically, the main approaches used to study cohesive sediments are laboratory flumes (van Leussen and Winterwerp, 1990; Schieber et al., 2007; Young and Southard, 1978), in situ flumes (Amos et al., 1992; Young and Southard, 1978), field studies (DeVries, 1992), and modeling (Sanford and Maa, 2001). The primary difficulty in studying erosion of cohesive sediments is the vast number of variables that influence erosion, ranging from grain size to ionic charge and sediment composition (Mehta et al., 1989; Schieber et al., 2007). Due to these difficulties, there are many unanswered questions about the elementary processes involved in the erosion of cohesive sediments.

Our experiments have some similarities with those of Winterwerp et al. (1993), in which the same sediments were subjected to several "tidal" cycles of erosion and deposition. In Winterwerp et al. (1993) experiments the bed was deposited from the water column, was highly erodible, suspended sediment concentration reached values up to $10 \mathrm{~g} \mathrm{~L}^{-1}$, and fluid mud formed in the slack water phase. On the contrary, our experiment had placed beds, which are known to be well consolidated and are likely to experience Type II erosion (Winterwerp et al., 2012). As a result, the suspended sediment concentration measured in our experiments never exceeded $1 \mathrm{~g} \mathrm{~L}^{-1}$, reflecting conditions commonly found in sheltered mudflats (Mariotti and Fagherazzi, 2011) and salt marshes (Christiansen et al., 2000). 


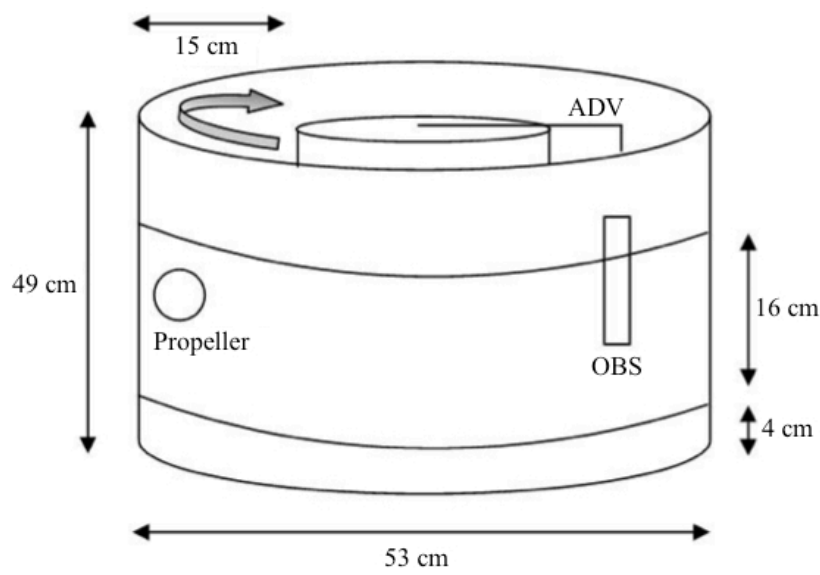

Fig. 1. Annular flume used for erosion experiments. Schematic of the flume apparatus. The flow in the flume is clockwise. The outer walls and the bottom of each flume were durable opaque plastic and the inside walls were glass.

Of increasing interest to the study of erosion of cohesive sediments is the role that biofilms play in physical processes (Paterson et al., 1998; Tolhurst et al., 2003, 2008; Underwood and Smith, 1998). A biofilm of microphytobenthos (MPBs), as used in this study, is a mixed community of microorganisms and their secretions, called extracellular polymeric substances (EPS) that surround sediment particles (Decho, 2000). It has been shown that microbial EPS contributes to grain-grain adhesion in fine sediments (Dade et al., 1990; Tolhurst et al., 1999; Yallop et al., 1994; Paterson, 1995; Taylor et al., 1999). De Brouwer et al. (2002) found no increase in sediment stability in the presence of extracted EPS, while Dade et al. (1990) saw an increase in sediment stability in the presence of extracted bacterial EPS, indicating that even in eroded material, residual EPS could cause graingrain adhesion. Additionally, studies that examined well developed biofilms reported an increase in erosion threshold and sediment stability (De Brouwer et al., 2000; Tolhurst et al., 2008; Paterson et al., 1998). Maximum erosion thresholds in tidal flats with diatom mats has been measured immediately preceding the maximum biomass of the mat (Stal, 2010), suggesting that the maturity of the diatom mat, in addition to the diatom biomass, can affect the erosion threshold and sediment stability. An experimental study showed that sediments with biofilm had a critical shear stress 5 to 10 times larger than abiotic sediments, while no significant differences were found between a weak and a fully developed biofilm (Neumeier et al., 2006).

To sum up, biofilms potentially stabilize cohesive sediments, but the magnitude of this effect is largely unknown. In particular, it is not clear how the type, structure, physiology, and development stage of the biofilm quantitatively affect erodability (Yallop et al., 1994). Three mechanisms of biogenic stabilization have been identified: network formation by the filamentous cyanobacteria, formation of amorphous organic linkages between non-cohesive sediment grains and accumulation of an EPS matrix (Yallop et al., 1994). While the amount of EPS is likely to be conserved during repeated erosion and deposition events, the biofilm network is destroyed when the biofilm is eroded away, strongly linking biostabilization to hydrodynamic disturbances experienced by the sediments.

Because of the finite time needed for a biofilm to develop, Mariotti and Fagherazzi (2012) suggested both the intensity and frequency of intermittent disturbances, such as tidal currents and wind waves, determine whether the biofilm can approach a fully developed state. This has prompted questions regarding the exposure of cohesive sediments with and without biofilms to repeated stresses, mimicking tidal conditions. Our experiments further explore this dichotomy to see if the sediment itself tends to reach a steady state of erosion after repeated exposure to flow.

This complex interplay between physical and biological processes can provide valuable information as to how mudflats and their ecosystems function in terms of cohesive sediment dynamics.

\section{Methods}

Annular flumes were designed and constructed based on modifying the design of previous flume studies (Fig. 1, see also Amos et al., 1992; Thompson et al., 2003). A propeller was placed in the flume at the top of the water column, which was $16 \mathrm{~cm}$ deep. An Acoustic Doppler Velocimeter (ADV) and an Optical Backscatter Sensor (OBS) were positioned in the flume, on the opposite side of the propeller. The ADV measured the three-dimensional velocity at $32 \mathrm{~Hz}$, sampling a volume $4 \mathrm{~cm}$ above the bed, centered in the flume cross section. An Optical Backscatter Sensor was positioned $5 \mathrm{~cm}$ below the water surface, and it was calibrated using samples from the water column.

Sediment was collected from a tidal flat in the Rowley River, Massachusetts, USA. Collection took place on days with average temperatures and no precipitation. At low tide, approximately the top $1-2 \mathrm{~cm}$ of sediment was removed from the mudflat. The sediment was sieved with a $2 \mathrm{~mm}$ mesh (\#10) to remove macrofauna. The sediment was $60-65 \%$ clay/silt and $35-40 \%$ sand $\left(d_{50}\right.$ of coarse fraction $=313.9 \mu \mathrm{m})$ and can be classified as a sandy cohesive mud. Estuarine water was collected during ebb tide and was later decanted to remove remaining suspended sediment. The sediment was frozen $\left(-18^{\circ} \mathrm{C}\right)$ for $12 \mathrm{~h}$ to eliminate excess biota (Ford et al., 1999; Tolhurst et al., 2008). The sediments were then thawed in a warm water bath. Once thawed, the sediment was mixed to make a homogenous slurry. An even layer of sediment $(\sim 4 \mathrm{~cm})$ was placed at the bottom of each flume. The tanks were then filled with salt water to a height 


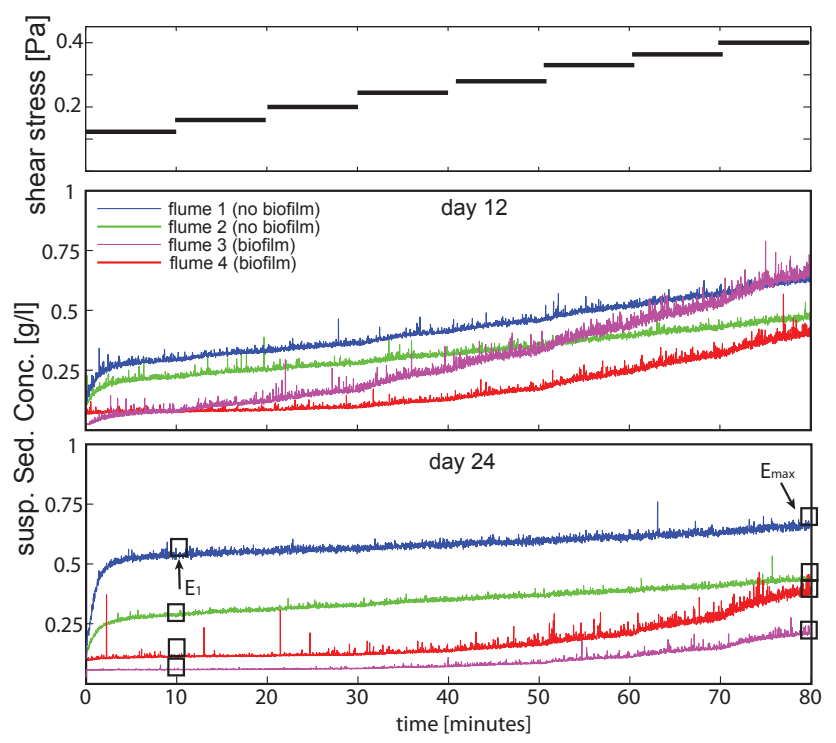

Fig. 2. Example of an erosion experiment. (A) Applied shear stresses. (B, C) Suspended sediment concentration as a function of time, in two different days. The values of $E_{1}$ and $E_{\max }$ are indicated by arrows.

of $16 \mathrm{~cm}$. In two control flumes bleach was regularly added to create an abiotic environment (Kim et al., 2008).

Erosion events were simulated at intervals varying between 1 and 12 days. The erosion frequency of 12 days mimics natural spring-neap tidal cycles. Additionally, 12 days is a realistic time interval between wind events that are able to create wave-induced resuspension (D'Alpaos et al., 2013). During each erosion event, the velocity of the propeller was increased every $10 \mathrm{~min}$ for $80 \mathrm{~min}$ until reaching a maximum value, generating currents ranging from $0.1 \mathrm{~m} \mathrm{~s}^{-1}$ to $0.2 \mathrm{~m} \mathrm{~s}^{-1}$. These velocities relate to shear stresses of approximately 0.1 to $0.4 \mathrm{~Pa}$ (Fig. $2 \mathrm{a}$ ). Then the propeller was removed from the flume and the sediment was allowed to settle until the next erosion event. Hence, our experiments mimic an environment in which sediments are eroded and deposited in the same area, such as a mudflat that is spatially uniform and isolated from external sediment sinks or sources.

Erosion was measured by using the turbidity of the water column, to determine the amount of suspended material. Bed shear stresses were computed with the quadratic stress law, $\tau=C_{\mathrm{D}} \rho U^{2}$, where $U$ is the total velocity magnitude, $\rho$ is the water density, set equal to $1035 \mathrm{~g} \mathrm{~L}^{-1}$, and $C_{\mathrm{D}}$ is the drag coefficient, set equal to 0.004 (see also Thompson et al., 2003). This method was found to be more reliable than using the Reynolds shear stresses, which were affected by large velocity fluctuations.

In the flumes without bleach, biofilms were cultured on the sediment surface. Fluorescent lamps (Hydrofarm FLT22 2 tube $\mathrm{T} 5,6400 \mathrm{~K}$ ) provided a $12 \mathrm{~h}$ light/dark cycle for photosynthetic growth of the biofilm that was already present in the natural sediments. Air temperature was kept within the range of $20-25^{\circ} \mathrm{C}$. Nutrients were regularly added according to the Redfield Ratio to maintain biofilm health. The water in the flumes was filtered using a filter pump to remove algae growing in the water column (Fluval 105 Filter Pump). Filtering was done at a slow rate so that the underlying sediment was not disturbed and after the sediment had settled out of the water column for at least $20 \mathrm{~h}$, so that no sediment nor suspended biofilm fragments were removed.

Biofilm density was determined using a Pulse Amplitude Modulator (PAM) sensor (Diving-PAM Underwater Fluorometer, Heinz Walz, Germany), which is a non-invasive method to determine biofilm growth. The minimum fluorescence yield was used as a proxy for chl $a$ concentration (Schreiber, 2004), which can be linearly related to the EPS concentrations (Buchsbaum et al., 2008). PAM measurements were taken every $24 \mathrm{~h}$, before the erosion events, under constant light conditions and keeping the probe approximately $4 \mathrm{~mm}$ above the sediment surface. Each measurement had 30 points, approximately equally distributed over the whole sediment surface, and averaged together. PAM measurements were calibrated to chl $a$ sampling. To measure chl $a$, samples of approximately $1 \mathrm{~g}$ were taken weekly from each flume using a shallow scoop. The samples were then frozen at $-18^{\circ} \mathrm{C}$. The chl $a$ from the samples was extracted using acetone and it was measured using a Turner Design Flourometer at $485 \mathrm{~nm}$ wavelength (Dalsgaard et al., 2000).

\section{Results}

Each erosion experiment consists of a time series of suspended sediment concentration. To synthetically describe each erosion experiment we used two parameters: $E_{\max }$ and $E_{1}$ (Fig. 2). $E_{\max }$ is the turbidity output from the final stage in the erosion experiment, and it is interpreted as the sediment erodability at moderate disturbances $(0.4 \mathrm{~Pa})$, which are often associated with tidal currents or light storms on mudflats (Mariotti and Fagherazzi, 2013). $E_{1}$ is the turbidity output after exposure to the lowest velocity, and it is interpreted as the erodability at low disturbances $(0.1 \mathrm{~Pa})$, such as those associated with daily breezes or limited tidal velocities. This value is likely associated with the erosion of the unconsolidated layer of the sediment deposited over a more consolidated bed.

In the bleached flumes (\#1 and 2), the chl $a$ concentration remained at a constant low value, indicating that they were indeed abiotic (Fig. 3a, b). In the flume with sporadic erosion events (\#3), the biofilm chl $a$ increased during periods without erosion, and decreased significantly after the two erosion events at day 12 and 22 (Fig. 3c). Visual and microscopic analysis revealed the presence of a diatom biofilm in flume 3, and an absence of it in flume 1 and 2. In the flume eroded every other day (\#4), there was a gradual increase in 

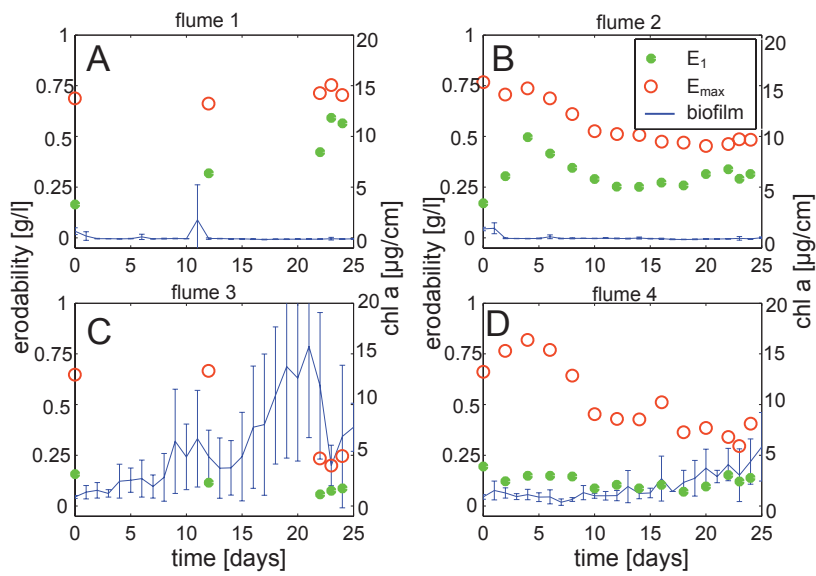

Fig. 3. Erodability $\left(E_{\max }\right.$ and $\left.E_{1}\right)$ and chl $a$ during the flume experiments. (A) Flume 1, eroded every 12 days. (B) Flume 2, eroded every other day. (C) Flume 3, eroded every 12 days. (D) Flume 4, eroded every other day. Flumes 1 and 2 were bleached.

biomass (Fig. 3d), which however remained much lower than that of flume 3 throughout the entire experiment.

In flume $1, E_{\max }$ was constant for the entire duration of the experiment and $E_{1}$ increased with time up to $200 \%$ of the initial value (Fig. 3a). During the erosion at day 12, the difference in $E_{\max }$ between flume 1 and 3 was small, but $E_{1}$ in the biotic flume was $50 \%$ lower than in the bleached flume. During the erosion at day 22 both $E_{\max }$ and $E_{1}$ in the biotic experiment were about $20 \%$ of those in the bleached one.

In both flume 2 and $4, E_{\max }$ decreased by about $30 \%$ and reached a similar value after about 10 days (Fig. 3b, d). In flume $4 E_{1}$ remained constant, while in flume $2 E_{1}$ increased by about $100 \%$ in the first 4 days (Fig. 3b, d).

\section{Discussion}

Sediment consolidation decreased the total erodability $\left(E_{\max }\right)$ in flume 2. Similarly, consolidation caused the decrease in total erodability in flume 4 , since the decrease occurred before the slight increase in biofilm biomass after day 15 . The presence of a small amount of biofilm in flume 4 is the reason why $E_{1}$ remained relatively low during the experiment. A small amount of biofilm stabilized the freshly deposited material over the more consolidated bed. The presence of a large amount of biofilm in flume 3 promoted a similar stabilization (Fig. 3c), while the presence of bleach removed this effect (Fig. 3a, b). As a result, in the bleached flumes, sediments were highly erodible, even when subjected to extremely low shear stresses. Sediments deposited from the previous erosion event were unable to stick to the underlying bed without biofilm, causing a progressive increase in $E_{1}$.

During the erosion at day 12 in flume 3, the presence of biofilm was unable to affect the total erosion $E_{\max }$, which resulted in a value almost identical to the bleached flume. Hence, the biofilm allowed stabilization with respect to very small disturbances $\left(E_{1}\right)$, but was unable to sustain moderate shear stresses $\left(E_{\max }\right)$. This observation is in accordance with the large decrease in biofilm biomass after the erosion events, likely caused by detachment of the biofilm. On the other hand, biofilms likely caused the sharp decrease in $E_{\max }$ in flume 4 at day 24. In this case the biofilm had enough time to grow and increase its resistance to erosion.

To summarize, biofilm biomass is strongly controlled by erosive events. Frequent disturbances prevent the establishment of a resistant biofilm. Nonetheless, a very weak biofilm is always present, increasing grain-grain cohesion, and promoting stabilization at very small shear stresses $\left(E_{1}\right)$. It is possible that this effect is promoted by the EPS present between the sediment grains, but without a coherent network which uniformly covers the bed and shelter it from the overlying flow. This type of biofilm persists even if the sediments are eroded, since the system is closed and all the eroded material is allowed to settle.

These findings are in agreement with previous research. The grain-to-grain adhesion observed at low values of shear stress agrees with the slight stabilization by non-structured biofilms found by Dade et al. (1990). Additionally, we confirmed that a mature biofilm can largely increase the stability of cohesive sediments (De Brouwer et al., 2000; Tolhurst et al., 2008; Paterson et al., 1998). Our findings support those previously discussed by Yallop et al. (1994) in that the structural state and maturity of the biofilm is critical in determining the magnitude of sediment stabilization.

In order to limit erosion at large shear stresses, the biofilm requires a prolonged period without disturbances to allow its growth, as suggested by previous modeling results (Mariotti and Fagherazzi, 2012). Once the biofilm reaches a critical state, it can significantly reduce the erodability at moderate disturbances (the decrease in $E_{\max }$ at day 24 in flume 3). To provide such stabilization, the biofilm needs to form a coherent network and cover the sediment surface.

\section{Conclusions}

Our experiments demonstrate that biofilm growth is strongly controlled by erosive events. If the biofilm is frequently disturbed, its growth is inhibited. In this case, it is able to offer stabilization only to very small disturbances, possibly stabilizing a thin layer of freshly deposited sediment. On the other hand, if long periods without erosion occur, the biofilm can fully develop and is able to reduce erodability from large shear stresses.

Even if no biofilm is visible on the sediment surface, small-magnitude biofilm stabilization may still occur. Biofilm EPS might periodically erode, deposit, and mix with the sediments, increasing grain-to-grain cohesion. This result emphasizes the need to quantify not only the biofilm 
biomass, but also its structure in order to understand biostabilization.

Finally, biofilm biostablization may occur at the same time as abiotic time-dependent stabilization, for instance in the consolidation of freshly deposited material, which occurs on time scales of a few weeks. This could possibly complicate the study of biostabilization in the field.

Acknowledgements. We would like to thank W. Fulweiler, A. Vieillard, and T. Viggato for their help. This research was supported by NSF awards OCE-0924287, DEB-0621014 (VCR-LTER program), and OCE-1238212 (PIE-LTER program). We also thank the Boston University UROP program for its generous support. We also thank J. Malarkey, G. Coco, and an anonymous reviewer for their contributions.

\section{References}

Amos, C. L., Grant, J., Daborn, G. R., and Black, K.: Sea Carousel - A benthic, annular flume, Estuar. Coast. Shelf S., 34, 557-577, 1992.

Buchsbaum, R. N., Deegan, L. A., Horowitz, J., Garritt, R. H., Giblin, A. E., Ludlam, J. P., and Shull, D. H.: Effects of regular salt marsh haying on marsh plants, algae, invertebrates and birds at Plum Island Sound, Massachusetts, Wetl. Ecol. Manag., 17, 469487, 2008 .

Christiansen, T., Wiberg, P. L., and Milligan, T. G.: Flow and sediment transport on a tidal salt marsh surface, Estuar. Coast. Shelf S., 50, 315-331, 2000.

Dade, W. B., Davis, J. D., Nichols, P. D., Nowell, A. R. M., Thistle, D., Trexler, M. B., and White, D. C.: Effects of bacterial exopolymer adhesion on the entrapment of sand, Geomicrobiol. J., 8, 1-16, doi:10.1080/01490459009377874, 1990.

D’Alpaos, A., Carniello, L., and Rinaldo, A.: Statistical mechanics of wind wave-induced erosion in shallow tidal basins: Inferences from the Venice Lagoon, Geophys. Res. Lett., 40, 3402-3407, doi:10.1002/grl.50666, 2013.

Dalsgaard, T. (Ed.), Nielsen, L. P., Brotas, V., Viaroli, P., Underwood, G., Nedwell, D., Sundback, K., Rysgaard, S., Miles, A., Bartoli, M., Dong, L., Thornton, D. C. O., Ottosen, L. D. M., Castaldelli, G., and Risgaard-Petersen, N.: Protocol Handbook for NICE - Nitrogen Cycling in Estuaries: A Project under the EU Research Programme: Marine Science and Technology (MAST III), National Environmental Research Institute, Silkeborg, Denmark, 2000.

De Brouwer, J. F. C., Bjelic, S., de Deckere, E. M. G. T., and Stal, L. $\mathrm{J}$. : Interaction between biology and sedimentology in a mudflat (Biezelingse Ham Westerschelde the Netherlands), Cont. Shelf Res., 20, 1159-1178, 2000.

De Brouwer, J. F. C., Ruddy, G. K., Jones, T. E. R., and Stal, L. J.: Sorption of EPS to sediment particles and the effect on the rheology of sediment slurries, Biogeochemistry, 61, 57-71, 2002.

Decho, A. W.: Microbial biofilms in intertidal systems: an overview, Cont. Shelf Res., 20, 1257-1273, 2000.

De Jonge, V. N. and van Beusekom, J. E. E.: Wind- and tide-induced resuspension of sediment and microphytobethos from tidal flats in the Ems estuary, Limnol. Oceanogr., 40, 766-778, 1995.
DeVries, J. W.: Field Measurements of the erosion of cohesive sediments, J. Coast. Res., 8, 312-318, 1992.

Fagherazzi, S. and Mariotti, G.: Mudflat runnels: Evidence and importance of very shallow flows in intertidal morphodynamics, Geophys. Res. Lett., 39, L14402, doi:10.1029/2012GL052542, 2012.

Ford, R. B., Thrush, S. F., and Probert, P. K.: Macrobenthic colonisation of disturbances on an intertidal sandflat: the influence of season and buried algae, Mar. Ecol.-Prog. Ser., 191, 163-174, 1999.

Kim, J., Pitts, B., Stewart, P. S., Camper, A., and Yoon, J.: Comparison of the antimicrobial effects of chlorine, silver Ion, and tobramycin on biofilm, Antimicrob. Agents Ch., 52, 1446-1453, 2008.

Mariotti, G. and Fagherazzi, S.: Asymmetric fluxes of water and sediments in a mesotidal mudflat channel, Cont. Shelf Res., 31, 23-36, 2011.

Mariotti, G. and Fagherazzi, S.: Modeling the effect of tides and waves on benthic biofilms, J. Geophys. Res.-Biogeo., 117, G04010, doi:10.1002/jgrf.20134, 2012.

Mariotti, G. and Fagherazzi, S.: Wind waves on a mudflat: The influence of fetch and depth on bed shear stresses, Cont. Shelf Res., 60, S99-S110, doi:10.1016/j.csr.2012.03.001, 2013.

Mehta, A., Hayter, E., Parker, W., Krone, R., and Teeter, A.: Cohesive sediment transport. I: Process description, J. Hydraul. Eng., 115, 1076-1093, 1989.

Neumeier, U., Lucas, C., and Collins, M.: Erodibility and erosion patterns of mudflat sediments investigated using an annular flume, Aquat. Ecol., 40, 543-554, 2006.

Paterson, D. M.: The biogenic structure of early sediment fabric visualized by low-temperature scanning electron microscopy, J. Geol. Soc., 152, 131-140, 1995.

Paterson, D. M., Wiltshire, K. H., Miles, A., Blackburn, J., Davidson, I., Yates, M. G., McGrorty, S., and Eastwood, J. A.: Microbiological mediation of spectral reflectance from intertidal cohesive sediments, Limnol. Oceanogr., 43, 1207-1221, 1998.

Sanford, L. P. and Maa, J. P.-Y.: A unified erosion formulation for fine sediments, Mar. Geol., 179, 9-23, 2001.

Schieber, J., Southard, J., and Thaisen, K.: Accretion of mudstone beds from migrating floccule ripples, Science, 318, 1760-1763, 2007.

Schreiber, U.: Pulse-Amplitude-Modulation (PAM) Fluorometry and Saturation Pulse Method: An Overview, in: Chlorophyll a Fluorescence, edited by: Papageorgiou, G. C. and Govindjee, P., Springer, the Netherlands, 279-319, 2004.

Stal, L. J.: Microphytobenthos as biogeomorphological force in intertidal sediment stabilization, Ecol. Eng., 36, 236-245, 2010.

Taylor, I. S., Paterson, D. M. Y., and Mehlert, A.: The quantitative variability and monosaccharide composition of sediment carbohydrates associated with intertidal diatom assemblages, Biogeochemistry, 45, 303-327, 1999.

Thompson, C. E. L., Amos, C. L., Jones, T. E. R., and Chaplin, J.: The manifestation of fluid-transmitted bed shear stress in a smooth annular flume-a comparison of methods, J. Coast. Res., 19, 1094-1103, 2003.

Tolhurst, T. J., Black, K. S., Shayler, S. A., Mather, S., Black, I., Baker, K., and Paterson, D. M.: Measuring the in situ shear stress of intertidal sediments with the Cohesive Strength Meter (CSM), Estuar. Coast. Shelf S., 49, 281-294, 1999. 
Tolhurst, T. J., Jesus, B., Brotas, V., and Paterson, D. M.: Diatom migration and sediment armouring - an example from the Tagus Estuary, Portugal, Hydrobiologia, 503, 183-193, 2003.

Tolhurst, T. J., Consalvey, M., and Paterson, D. M.: Changes in cohesive sediment properties associated with the growth of a diatom biofilm, Hydrobiologia, 596, 225-239, 2008.

Underwood, G. J. C. and Smith, D. J.: Predicting epipelic diatom exopolymer concentrations in intertidal sediments from sediment chlorophyll a, Microb. Ecol., 35, 116-125, 1998.

van Leussen, W. and Winterwerp, J. C.: Laboratory experiments on sedimentation of fine-grained sediments: A state-of-the-art review in the light of Experiments with the Delft Tidal Flume, in: Residual Currents and Long-term Transport, edited by: Cheng, R. T., Springer, New York, USA, 241-259, 1990.

Winterwerp, J. C., Cornelisse, J. M., and Kuijper, C.: A laboratory study on the behavior of mud from the Western Scheldt under tidal conditions, in: Nearshore and Estuarine Cohesive Sediment Transport, edited by: Mehta, A. J., American Geophysical Union, Washington D.C., USA, 295-313, 1993.
Winterwerp, J. C., van Kesteren, W. G. M., van Prooijen, B., and Jacobs, W.: A conceptual framework for shear flow-induced erosion of soft cohesive sediment beds, J. Geophys. Res.-Oceans, 117, 2156-2202, doi:10.1029/2012JC008072, 2012.

Woodroffe, C. D.: Coasts: form, process and evolution, Cambridge University Press, Cambridge, United Kingdom, 2002.

Yallop, M. L., de Winder, B., Paterson, D. M., and Stal, L. J.: Comparative structure, primary production and biogenic stabilization of cohesive and non-cohesive marine sediments inhabited by microphytobenthos, Estuar. Coast. Shelf S., 39, 565-582., 1994.

Young, R. N. and Southard, J. B.: Erosion of fine-grained marine sediments: sea-floor and laboratory experiments, Geol. Soc. Am. Bull., 89, 663-672, 1978. 